\title{
An Investigation into the Professional Commitment of Chinese Project Management Professionals
}

\author{
Xiaojin Wang ${ }^{1} \&$ Jianrong Shen ${ }^{1}$ \\ ${ }^{1}$ Systems Engineering Research Center, Yunnan University, China \\ Correspondence: Xiaojin Wang, Systems Engineering Research Center, Yunnan University, No. 2 Cuihu Bei Lu, \\ Kunming, China. Tel: 86-871-503-3771. E-mail: xjwang@ynu.edu.cn
}

Received: January 31, 2012 Accepted: February 23, 2012 Online Published: May 16, 2012

doi:10.5539/ijbm.v7n10p156

URL: http://dx.doi.org/ijbm.v7n10p156

\begin{abstract}
This paper reports the results of a questionnaire survey of Chinese PM Professionals' professional commitment (PC). It confirms the three PC dimensions of PM Career Pursuit Commitment, PM Reference Group Commitment, and PM Leisure Time Commitment. It reveals that the PM professionals' PC is positively correlated with their organizational positions, work experience, PM training, and their organizational commitment (OC). The PM professionals' PC and OC are both quite high, and their PC is even higher than their OC. In those organization regarding important the PM approach, their employed PM professionals' OC can be further enhanced.
\end{abstract}

Keywords: project management professional, professional commitment, organizational commitment

\section{Introduction}

In 2000 and 2001, the 2 internationally-recognized project management (PM) certification programs were respectively introduced into the China Mainland. One is the Project Management Professional (PMP) certification of the Project Management Institute (PMI), and the other is the four levels PM certification of the International Project Management Association (IPMA). During the first decade of the 21 century, the PM profession developed very quickly in the China Mainland. For example, the yearly number of PMP certificate examinees has increased from 316 of the year 2000 to 14720 of the year 2010. A great number of Chinese PM Practitioners are expected to sit for the PMP certification exam in the near future. These PMP credential holders and candidates (Hereafter called "Chinese PM Professionals") are active members of the Chinese PM professional community. They are playing an important role in promoting the development of the PM profession. However, little research has been conducted about the Chinese PM professionals' commitment to the PM profession.

\section{Literature Review and Research Questions}

\subsection{Measuring Professional Commitment}

Professional commitment (PC) is a kind of work commitment that emphasizes the importance of a profession in one's total life (Morrow, 1993). As an important factors determining people's work behavior, the topic of PC has been attracting many researchers' attention, e.g., Dwivedula and Bredillet (2010), Teng, et al (2009), Chen, et al (2008), Greenfield, Norman and Wier (2008), McComb (2006), Wang and Armstrong (2004), Lee, Carswell and Allen (2000), Hoff (2000), Dwyer, Welker and Friedberg (2000), Irving, Coleman and Cooper (1997), and Meyer, Allen and Smith (1993). Previous studies have contributed to the literature such aspects as measurements of PC, relationships between PC and organizational commitment (OC), and relationships between PC and its antecedent or consequence variables.

In the literature, some researchers measure PC using the same way of measuring $\mathrm{OC}$, without any consideration of how a professional community differs from an employing organization. For example, the two widely-used PC measurements, Aranya, Pollock and Amernic's (1981) one-dimensional scale and Meyer, Allen and Smith's (1993) three-component PC model, are modified from their OC versions. They just substitute the word 'profession' for 'organization'. Greenfield, Norman and Wier (2008) use the one-dimensional scale to investigate senior-level business students' professional commitment. Yetmar and Eastman (2000) use the one-dimensional scale to investigate tax practitioners' professional commitment. Dwivedula and Bredillet (2010) use the three-component model to investigate project workers' professional commitment. McComb (2006) uses the 
three-component model to investigate general practitioners' occupational commitment.

Some researchers specially develop PC measurement scales according to the characteristics of a profession, such as Blau and Lunz's (1998) one-dimensional scale consisting of 5 items, and Wang's (2001) three-dimensional model of 9 items. Wang (2001) develops the three-dimensional (Career pursuit commitment, Reference group commitment, and Leisure time commitment) model as part of the PM's professional culture. Regarding a professional community as quite different from an employing organization, he establishes the model on the basis of Salaman's (1974) key components of a professional community, independently from the concepts and measurements of OC. Salaman's key components are: (1) professionals' self identification with their profession, (2) professionals using peers as a reference group, and (3) professionals carrying work activities, interests and relationships into non-work lives. This kind of work-leisure relationship is also supported by Parker's (1972) theory of work-leisure relationships. Parker (1972) identifies three patterns of work-leisure relationships, i.e., extension, opposition, and neutrality, and relates each of them to a set of associated variables. From the theory, it is clear that professionals are expected to be extension-pattern-oriented, that is, they have a strong tendency to extension of work into leisure.

Through a questionnaire survey of Australian PM professionals, Wang (2001) obtains the following 3 dimensions of professional commitment: PM Career Pursuit - PM professionals take PM as their permanent career pursuit rather than a stepping-stone to other professions; PM Reference Group - PM professionals use other members of the PM profession as their important reference group for their PM performance; and Leisure Time for PM - PM professionals contribute some of their leisure time to PM professional activities. This paper uses Wang's (2001) three dimensional model to operationalize the concept of professional commitment.

\subsection{Why Use Wang's Model}

There are three major reasons for using Wang's model. Firstly, Wang's model is a multidimensional one. Although some researchers regard professional commitment as a one-dimensional concept, most researchers agree to its multidimensional nature. Various studies supporting PC's multidimensional nature have been reported, such as Dwivedula and Bredillet (2010) and McComb (2006).

Secondly, the literature does support the idea about the difference between a professional community and an employing organization. Van Maanen and Barley (1984) see organization and occupation as two alternative perspectives from which to view how work is organized and interpreted. According to Van Maanen and Barley (1984), work itself is a focal concept in a professional community, but work is only a small part of the relationships in an employing organization, and professionals concentrate upon the meaning of work for themselves who do it, but employees accentuate the meaning of work for others (employers) in an employing organization. On the basis of a literature review, Wang and Armstrong (2004) summarize that professionals usually see their profession as a permanent career instead of a stepping-stone to another occupation, but professionals often have relatively short tenures in a particular organization due to the cross-organizational labor market. It is much easier for professionals to move from organization to organization than to change their occupation.

Thirdly, the PM professional community is now well-developed around global and national PM associations, such as PMI, IPMA, and Australian Institute of Project Management (AIPM), and the PM professional community is playing a very important role in enhancing PM professionals' professional commitment. According to Van Maanen and Barley's (1984) general definition of professional community, the PM professional community can be defined as a group of people who consider themselves to do the same work of project management, who draw their identity from the work, who share with one another a set of work-related values and beliefs, and whose social relationships meld work and leisure. The travel convenience has significantly increased the number of formal and informal project management meetings, and the electronic networking has resulted in the formation of countless on-line communities of PM practices. Face-to-face contacts and electronic communications among PM professionals certainly have positive effects on PM professionals' career development and professional commitment, although empirical research is required in this area. Previous research about teacher's professional community shows that professional community and professional development are closely linked and mutually supportive (Little, 2006), and a professional community is very important for teachers to improve their instruction (Wahlstrom and Louis, 2008).

\subsection{Professional Commitment and Organizational Commitment}

Because most professionals are employed by organizations, professionals' organizational commitment is often investigated together with their professional commitment. Gouldner (1957) uses the concepts of cosmopolitan and local to describe professionals' loyalty to profession and employing organization. Cosmopolitans' 
commitment to profession is higher than to organization, and Locals' commitment to profession is lower than to organization. Due to the great amount of time and energy spending in learning PM knowledge and skills, greater opportunities of horizontal job mobility from organization to organization, and the temporary nature of project work, PM professionals are more cosmopolitan than local (Wang and Armstrong, 2004). However, this doesn't mean that PM professionals' PC and OC are conflicting and negatively correlated. Previous studies show that PM professionals' PC and OC are positively correlated (Dwivedula and Bredillet 2010, Li and Shi 2007, Wang and Armstrong 2004). Various studies about other professions also reveal the positive correlation between PC and OC, such as Baugh and Roberts (1994), Tang and Duan (2006), and Liu (2006).

The literature provides only very limited studies about PM professionals' PC and OC and the relationships between their PC and OC. With respect to Chinese PM Professionals' PC and OC, Li and Shi's (2007) study is the only one revealed from the literature review. PM professionals' PC and OC are worthy further investigations, given the increasing popularity of the PM approach in various industries and the quick growth of the PM profession. Chinese PM Professionals' PC and OC are especially worthy further investigation because the Chinese PM profession is developing very quickly. Bredillet (2009) anticipates that the number of PMP certificate holders and IPMA certificate holders in China will increase from 44000 of the year 2008 to 441000 of the year 2025.

\subsection{Demographics' Effect on Professional Commitment}

A profession is such an occupation requiring advanced education, special training, and a lot of practices (Wang and Armstrong, 2004). After being educated in schools and universities, one must receive formal professional training, accumulate several years' practical experience, and even obtain a professional certificate before he/she is recognized by their peers as a true professional. For example, to be PMP certified, one must complete a formal PM training course of minimum 35 contact hours and have minimum 3 years (for Bachelor degree holders) or 5 years (for those below Bachelor degree) professional PM experience (PMI, 2011). PM professional trainings can transmit relevant knowledge, skills, values and beliefs to students, which will help to establish their professional identity and commitment. Wang's (2001) investigation into Australian PM Professionals reveals that those with postgraduate or PMP exam preparation PM training are significantly more committed to the PM profession $(\mathrm{P}<0.01)$, compared with others without such training. He also finds out that those with 6 years and above professional PM experience are more committed to the PM profession than others with below 6 years experience. Various studies of other professions also support the idea that practical experience is important in enhancing professionals' PC. For example, Lian (2004) reports that the professional commitment of expert teachers with more than 15 years teaching experience is significantly higher $(\mathrm{p}<0.001)$ than the PC of proficient teachers (with 6-14 years teaching experience) and novice teachers (with $0-5$ years teaching experience).

\subsection{Research Questions}

On the basis of the above literature review, this research is aimed to the following questions: (1) Can the PC's 3 dimensions (Career Pursuit, Reference Group, and Leisure Time Commitment) be confirmed among Chinese PM Professionals? (2) To what degree are Chinese PM Professionals committed to the PM profession? (3) What is the relationship between Chinese PM Professionals' PC and OC? (4) Which factors have significant effects on Chinese PM Professionals' PC and OC? (5) Which implications can be drawn from the answers to the above questions for the PM profession and employing organizations?

\section{Research Method}

On the basis of Wang's (2001) PC model and its measuring scale of 9 items, this research develops a measuring scale of 12 items in Chinese (Table 1). The respondents are required to rate the importance of each item on a Likert scale from " 1 very unimportant" to " 5 very important".

For the comparative purpose, a measuring scale of OC is developed on the basis of the PC scale, just substituting the word 'organizational' for 'professional' and 'my employing organization' for 'project management' or 'the PM profession'.

The survey was conducted on-line in November and December 2010. The target respondents were PMP certificate holders and PMP candidates who were willing to obtain the PMP certificate in the future. 
Table 1. Measuring items of professional commitment

\begin{tabular}{lll}
\hline Variable & Short name & Full item \\
\hline Career & P-Identity & Belong to the professional community of project management \\
Pursuit & P-Knowledge & Improve my knowledge in project management \\
Commitment & P-Career & Have a permanent career within the PM profession \\
& P-Reputation & Building my professional reputation in project management \\
Reference & P-Salary & Have an adequate level of salary relative to others in the PM profession \\
Group & P-Contact & Keep contact with others in the PM profession \\
Commitment & P-Values & Have the same work-related values and beliefs as others in the PM profession \\
& P-Excellence & Earn excellence in the eyes of others in the PM profession \\
Leisure & P-LDiscussion & Talk about project management in my leisure time \\
Time & P-LParty & Participate in professional PM activities in my leisure time \\
Commitment & P-LVolunteer & To be a volunteer serving the PM profession in my leisure time \\
& P-LPromotion & Publicize the PM profession in my leisure time \\
\hline
\end{tabular}

The survey produced 236 responses. Of which 7 respondents were not among the target population, and therefore excluded. The remaining 229 responses were used as the research data.

Factor analysis was used to explore the dimensions of Chinese PM Professionals' PC. The scale reliabilities were tested using Cronbach Alphas. Descriptive and inferential statistics were used to answer the research questions.

\section{Research Results}

\subsection{Description of the Sample}

The main demographics of the 229 respondents are showed in Table 2. The sample is a good representative of the population of Chinese PM Professionals.

Table 2. Respondents' Demographic Profile

\begin{tabular}{lcc}
\hline Demographic Profile & Frequency (Number) & Percent (\%) \\
\hline By Gender: & & \\
- Male/Female & $163 / 66$ & $71.2 / 28.8$ \\
By Industry: & 107 & 46.7 \\
- IT & 31 & 13.5 \\
- Manufacturing & 24 & 10.5 \\
- Construction & 21 & 9.2 \\
- Telecom & 46 & 20.1 \\
- Other & & \\
By City: & $97 / 41 / 17 / 74$ & $42.4 / 17.9 / 7.4 / 32.3$ \\
Beijing/Shenzhen/Shanghai/Other & & \\
By Position in organizations: & 126 & 55.0 \\
- Middle manager & 81 & 35.4 \\
- Team member & 22 & 9.6 \\
- Senior manager & & \\
By PM experience: & 108 & 47.2 \\
- Below 3 years & 79 & 34.5 \\
- 3-5 years & 42 & 18.3 \\
- 6 years \& above & & \\
By Formal PM Training: & 110 & 48.0 \\
- Above 10 days & 19 & 8.3 \\
- 9-10 days & 23 & 10.0 \\
- 7-8 days & 77 & 33.6 \\
- below 7 days & & \\
By PMP certificate: & 115 & 50.2 \\
- Already holding & 80 & 34.9 \\
- Be studying preparation course & 34 & 14.8 \\
- Will obtain in the future & & \\
\hline & $\quad$ &
\end{tabular}


The respondents were also required to rate how important their employing organizations regard the PM approach as a way for improving organizational performance (Hereafter called PM Importance). The results are as follows: (1) Very important: 16 respondents (7.0\%), (2) Important: 63 respondents (27.5\%), (3) So-so: 98 respondents (42.8\%), (4) Unimportant: 43 respondents (18.8\%), and (5) Very Unimportant: 9 respondents (3.9\%).

\subsection{Dimensions of Chinese PM Professionals' $P C$}

The 12 items measuring PC were analyzed using Principal Axis Factoring and Varimax rotation with Kaiser Normalization. The factor analysis obtained a quite clear structure consisting of 3 factors, which in total explain $60 \%$ of the variance (Table 3). The factors represent the 3 dimensions of the PC model, i.e., Career Pursuit Commitment, Reference Group Commitment, and Leisure Time Commitment.

Table 3. Factor analysis result of professional commitment

\begin{tabular}{lccc}
\hline \multicolumn{1}{c}{ Measuring Item } & $\begin{array}{c}\text { Factor 1 (Leisure } \\
\text { time commitment) }\end{array}$ & $\begin{array}{c}\text { Factor 2 (Career } \\
\text { pursuit commitment) }\end{array}$ & $\begin{array}{c}\text { Factor 3 (Reference } \\
\text { group commitment) }\end{array}$ \\
\hline P-LParty & 0.775 & & \\
P-LVolunteer & 0.756 & & \\
P-LPromotion & 0.722 & & \\
P-Ldiscussion & 0.639 & & \\
P-Knowledge & & 0.617 & \\
P-Identity & & 0.599 & \\
P-Reputation & & 0.514 & 0.729 \\
P-Career & 0.339 & 0.453 & 0.518 \\
P-Salary & & 0.396 & 0.506 \\
P-Excellence & & & \\
P-Contact & & & \\
P-Values & 0.416 & & \\
\hline
\end{tabular}

Note: factor loadings less than 0.3 are suppressed.

On the basis of the factor analysis result, scale reliabilities were calculated (Table 4).

Table 4. Scale reliabilities

\begin{tabular}{lcc}
\hline Scale & Cronbach's Alpha & N of Items \\
\hline Professional commitment & 0.846 & 12 \\
Career pursuit commitment & 0.691 & 5 \\
Reference group commitment & 0.728 & 3 \\
Leisure time commitment & 0.844 & 4 \\
\hline
\end{tabular}

The factor analysis of the 12 items measuring OC didn't reveal the same dimensional structure as the result of PC factor analysis. However, the OC scale has also a good internal consistency. Its Cronbach's Alpha is 0.711.

\subsection{Chinese PM Professionals' $P C$ and $O C$}

To know the degree to which Chinese PM Professionals are committed to the PM profession, summated scales (means and standard deviations) were computed for each dimension of the PC model, and also for the whole PC scale. To know their commitment degree to employing organizations, summated scales were computed for the whole OC scale. Paired sample t-test was used to investigate the significance of the differences between the summated scales. Pearson correlations were calculated to explore the relationships between the summated scales. The results are shown in Table 5. 
Table 5. Summated scales for PC and OC

\begin{tabular}{lcccl}
\hline & Mean & S.D. & Paired sample t-test (2-tailed) & Pearson Correlation (2-tailed) \\
\hline OC & 3.73 & 0.38 & $t(228)=6.477, \mathrm{p}<0.001$ & $0.641, \mathrm{p}<0.001$ \\
PC & 3.89 & 0.48 & & \\
CPC & 4.04 & 0.52 & CPC \& RGC: $\mathrm{t}(228)=-0.671, \mathrm{p}>0.100$ & CPC \& RGC: $0.491, \mathrm{p}<0.001$ \\
RGC & 4.07 & 0.61 & CPC \& LTC: $\mathrm{t}(228)=10.889, \mathrm{p}<0.001$ & CPC \& LTC: $0.410, \mathrm{p}<0.001$ \\
LTC & 3.56 & 0.68 & RGC \& LTC: $\mathrm{t}(228)=12.185, \mathrm{p}<0.001$ & RGC \& LTC: $0.534, \mathrm{p}<0.001$
\end{tabular}

Note: OC: Organizational commitment; PC: Professional commitment; CPC: Career pursuit commitment; RGC: Reference group commitment; LTC: Leisure time commitment

\subsection{Demographics' Impacts on PC}

To exam demographics' impacts on PC, one-way ANOVA analysis was used. It revealed that the following kinds of demographics have significant impacts on Chinese PM Professionals' PC $(p<0.05)$ : Position in organization, PM experience, and PM formal training. Then, Independent Samples Test was used to further explore the above demographics' impacts on Chinese PM Professionals' PC. The t-test results are shown in Table 6, Table 7, and Table 8 .

Table 6. Position-Grouped Summated Scale of PC

\begin{tabular}{llcccl}
\hline & Position & $\mathrm{N}$ & Mean & S.D. & Independent samples t-test \\
\hline Professional & Senior Manager (SM) & 22 & 4.22 & 0.50 & SM \& MM: $\mathrm{t}(146)=3.045, \mathrm{p}<0.01$ \\
commitment & Middle Manager (MM) & 126 & 3.89 & 0.45 & SM \& TM: $\mathrm{t}(101)=3.677, \mathrm{p}<0.001$ \\
(PC) & Team Member (TM) & 81 & 3.79 & 0.48 & MM \& TM: $\mathrm{t}(205)=1.598, \mathrm{p}>0.05$ \\
Career pursuit & Senior Manager (SM) & 22 & 4.30 & 0.66 & SM \& MM: $\mathrm{t}(146)=2.163, \mathrm{p}<0.05$ \\
commitment & Middle Manager (MM) & 126 & 4.05 & 0.46 & SM \& TM: $(101)=2.592, \mathrm{p}<0.05$ \\
$(\mathrm{CPC})$ & Team Member (TM) & 81 & 3.95 & 0.54 & MM \& TM: $\mathrm{t}(205)=1.512, \mathrm{p}>0.05$ \\
Ref. group & Senior Manager (SM) & 22 & 4.50 & 0.53 & SM \& MM: $\mathrm{t}(146)=3.174, \mathrm{p}<0.01$ \\
commitment & Middle Manager (MM) & 126 & 4.08 & 0.58 & SM \& TM: $(101)=4.003, \mathrm{p}<0.001$ \\
(RGC) & Team Member (TM) & 81 & 3.92 & 0.62 & MM \& TM: $\mathrm{t}(205)=1.898, \mathrm{p}>0.05$ \\
Leisure time & Senior Manager (SM) & 22 & 3.90 & 0.69 & SM \& MM: $\mathrm{t}(146)=2.217, \mathrm{p}<0.05$ \\
commitment & Middle Manager (MM) & 126 & 3.55 & 0.67 & SM \& TM: $\mathrm{t}(101)=2.525, \mathrm{p}<0.05$ \\
(LTC) & Team Member (TM) & 81 & 3.49 & 0.67 & MM \& TM: $\mathrm{t}(205)=0.661, \mathrm{p}>0.05$ \\
\hline
\end{tabular}

Table 7. Experience-Grouped Summated Scale of PC

\begin{tabular}{|c|c|c|c|c|c|}
\hline & Position & $\mathrm{N}$ & Mean & S.D. & Independent samples t-test \\
\hline \multirow{3}{*}{$\begin{array}{l}\text { Professional } \\
\text { commitment } \\
\text { (PC) }\end{array}$} & 1. Below 3 years & 108 & 3.80 & 0.48 & $1 \& 2: \mathrm{t}(185)=-1.548, \mathrm{p}>0.05$ \\
\hline & $2.3-5$ years & 79 & 3.91 & 0.45 & $1 \& 3: \mathrm{t}(148)=-3.039, \mathrm{p}<0.01$ \\
\hline & 3. 6 years \& above & 42 & 4.07 & 0.49 & $2 \& 3: \mathrm{t}(119)=-1.789, \mathrm{p}>0.05$ \\
\hline \multirow{3}{*}{$\begin{array}{l}\text { Career pursuit } \\
\text { commitment } \\
(\mathrm{CPC})\end{array}$} & 1. Below 3 years & 108 & 3.96 & 0.49 & $1 \& 2: \mathrm{t}(185)=-0.977, \mathrm{p}>0.05$ \\
\hline & $2.3-5$ years & 79 & 4.04 & 0.51 & $1 \& 3: \mathrm{t}(148)=-3.102, \mathrm{p}<0.01$ \\
\hline & 3. 6 years $\&$ above & 42 & 4.25 & 0.54 & $2 \& 3: \mathrm{t}(119)=-2.128, \mathrm{p}<0.05$ \\
\hline \multirow{3}{*}{$\begin{array}{l}\text { Ref. group } \\
\text { commitment } \\
\text { (RGC) }\end{array}$} & 1. Below 3 years & 108 & 3.97 & 0.64 & $1 \& 2: \mathrm{t}(185)=-1.495, \mathrm{p}>0.05$ \\
\hline & $2.3-5$ years & 79 & 4.10 & 0.54 & $1 \& 3: \mathrm{t}(148)=-2.420, \mathrm{p}<0.05$ \\
\hline & 3. 6 years $\&$ above & 42 & 4.25 & 0.62 & $2 \& 3: \mathrm{t}(119)=-1.340, \mathrm{p}>0.05$ \\
\hline \multirow{3}{*}{$\begin{array}{l}\text { Leisure time } \\
\text { commitment } \\
\text { (LTC) }\end{array}$} & 1. Below 3 years & 108 & 3.48 & 0.66 & $1 \& 2: \mathrm{t}(185)=-1.316, \mathrm{p}>0.05$ \\
\hline & 2. $3-5$ years & 79 & 3.61 & 0.68 & $1 \& 3: \mathrm{t}(148)=-1.909, \mathrm{p}>0.05$ \\
\hline & 3. 6 years \& above & 42 & 3.71 & 0.68 & $2 \& 3: \mathrm{t}(119)=-0.771, \mathrm{p}>0.05$ \\
\hline
\end{tabular}


Table 8. PMP-Training-Grouped Summated Scale of PC

\begin{tabular}{lccccc}
\hline & Position & $\mathrm{N}$ & Mean & S.D. & Independent samples t-test \\
\hline Professional & 1. 9 days and above & 129 & 3.98 & 0.47 & $\mathrm{t}(227)=3.337, \mathrm{p}<0.01$ \\
commitment (PC) & 2. Below 9 days & 100 & 3.77 & 0.47 & \\
Career pursuit & 1. 9 days and above & 129 & 4.11 & 0.53 & $\mathrm{t}(227)=2.191, \mathrm{p}<0.05$ \\
commitment (CPC) & 2. Below 9 days & 100 & 3.96 & 0.48 & \\
Reference group & 1. 9 days and above & 129 & 4.14 & 0.58 & $\mathrm{t}(227)=2.266, \mathrm{p}<0.05$ \\
commitment (RGC) & 2. Below 9 days & 100 & 3.96 & 0.63 & \\
Leisure time & 1. 9 days and above & 129 & 3.70 & 0.67 & $\mathrm{t}(227)=3.415, \mathrm{p}<0.01$ \\
commitment (LTC) & 2. Below 9 days & 100 & 3.40 & 0.64 & \\
\hline
\end{tabular}

\subsection{The Effect of PM Importance on OC}

The one-way ANOVA analysis revealed that the factor of PM Importance has significant impact on Chinese PM Professionals' OC $(p<0.05)$. Then, Independent Samples Test was used to further explore its impacts on Chinese PM Professionals' PC and OC. The t-test results are shown in Table 9.

Table 9. PM-Importance-Grouped Summated Scale of PC and OC

\begin{tabular}{llllll}
\hline & Importance degree & $\mathrm{N}$ & Mean & S.D. & Independent samples t-test \\
\hline Professional & 1. Important & 79 & 3.93 & 0.48 & $1 \& 2: \mathrm{t}(175)=0.951, \mathrm{p}>0.05$ \\
commitment & 2. So-so & 98 & 3.86 & 0.48 & $1 \& 3: \mathrm{t}(129)=0.667, \mathrm{p}>0.05$ \\
(PC) & 3. Unimportant & 52 & 3.87 & 0.48 & $2 \& 3: \mathrm{t}(148)=-0.146, \mathrm{p}>0.05$ \\
Career pursuit & 1. Important & 79 & 4.10 & 0.49 & $1 \& 2: \mathrm{t}(175)=1.045, \mathrm{p}>0.05$ \\
commitment & 2. So-so & 98 & 4.02 & 0.51 & $1 \& 3: \mathrm{t}(129)=1.402, \mathrm{p}>0.05$ \\
$(\mathrm{CPC})$ & 3. Unimportant & 52 & 3.97 & 0.56 & $2 \& 3: \mathrm{t}(148)=0.569, \mathrm{p}>0.05$ \\
Reference group & 1. Important & 79 & 4.14 & 0.52 & $1 \& 2: \mathrm{t}(175)=1.630, \mathrm{p}>0.05$ \\
commitment & 2. So-so & 98 & 3.99 & 0.62 & $1 \& 3: \mathrm{t}(129)=0.466, \mathrm{p}>0.05$ \\
(RGC) & 3. Unimportant & 52 & 4.09 & 0.65 & $2 \& 3: \mathrm{t}(148)=-0.895, \mathrm{p}>0.05$ \\
Leisure time & 1. Important & 79 & 3.56 & 0.70 & $1 \& 2: \mathrm{t}(175)=-0.016, \mathrm{p}>0.05$ \\
commitment & 2. So-so & 98 & 3.56 & 0.68 & $1 \& 3: \mathrm{t}(129)=-0.243, \mathrm{p}>0.05$ \\
(LTC) & 3. Unimportant & 52 & 3.59 & 0.65 & $2 \& 3: \mathrm{t}(148)=-0.243, \mathrm{p}>0.05$ \\
Organizational & 1. Important & 79 & 3.82 & 0.38 & $1 \& 2: \mathrm{t}(175)=2.081, \mathrm{p}<0.05$ \\
commitment & 2. So-so & 98 & 3.70 & 0.38 & $1 \& 3: \mathrm{t}(129)=2.741, \mathrm{p}<0.01$ \\
$(\mathrm{OC})$ & 3. Unimportant & 52 & 3.64 & 0.37 & $2 \& 3: \mathrm{t}(148)=1.002, \mathrm{p}>0.05$ \\
\hline
\end{tabular}

\section{Discussion}

\subsection{The Dimensions of Chinese PM Professionals' PC}

The factor analysis results in a very clear PC structure consisting of the 3 dimensions: Career Pursuit Commitment (CPC), Reference Group Commitment (RGC) and Leisure Time Commitment (LTC). The overall PC scale and its sub-scales of CPC, RGC and LTC all have a satisfactory internal consistency represented by Cronbach's coefficient alpha. All the measuring items have factor loadings over 0.3 on relevant factors. Except the measuring item "P-Salary: Have an adequate level of salary relative to others in the PM profession", all others fall into the factor (sub-commitment) they were intended to measure. The item P-Salary was intended to measure the Reference Group Commitment, but in the factor analysis resolution, it falls into the factor of Career Pursuit Commitment. In Wang's (2001) investigation of Australian PM Professionals, the same result was obtained, that is, the P-Salary item belonged to the factor of Career Pursuit Commitment instead of Reference 
Group Commitment. The reason could be that PM professionals regard earning salary as an important component of their PM career pursuit. Their salary levels are related to their work performance much more than to their peers' salary levels.

The research can confirm the 3 dimensional PC model originally developed by Wang (2001). Compared with the PC models (for example, Meyer, Allen and Smith, 1993) derived from relevant OC models, Wang's PC model is developed on the basis of considering the main characteristics of a professional community. It is much more useful for PM associations to enhance the development of the PM profession and the PM professional community. Only those individuals who regard PM as their permanent career, use PM peers as reference group and contribute some leisure time to the PM profession can be recognized as true PM Professionals. Just doing some work of project management is no enough. It is suggested that PM associations make greater efforts to help PM professionals establish and develop their PM career pursuit commitment, PM reference group commitment and PM leisure time commitment. PM is now on the way from an emerging profession to a mature profession. To be mature, the PM profession must have its own career ladder, peer heroes, and PM related leisure activities (such as PM related movies, TV programs, and songs to attract members' leisure time). The PM profession has much to do in these three aspects.

\subsection{Chinese PM Professionals' $P C$ and $O C$}

Chinese PM Professionals' commitment to the PM profession and their employing organizations are both relatively high, respectively obtaining the mean scores of 3.89 and 3.73 with small standard deviations. Their PC and $\mathrm{OC}$ are significantly positively correlated $(\mathrm{r}=0.64, \mathrm{p}<0.001)$. This finding confirms the previous research result of the supporting relationships between PC and OC, such as Dwivedula and Bredillet (2010), Wang and Armstrong (2004). The more a professional is committed to the profession, the more he (she) is committed to his (her) employing organization. This kind of relationship between PC and OC can establish a sound basis for employing organization and PM association to work together for the purpose of win-win development.

At the significance level of 0.001 , Chinese PM Professionals are more committed to the PM profession than to the employing organizations. This finding also confirms Wang and Armstrong's (2004) finding of PM professionals' cosmopolitan nature. As early as in 1995, Stewart (1995) predicted that careers would be defined less by organizations and more by professions, that is, what you do would be more important than where you work. It is relatively easy for a professional to move from organization to organization, but quite difficult to change his/her profession. Due to the temporary nature of project work, PM professionals are usually ready for job mobility from project to project and from organization to organization. In order to enhance PM professionals' work commitment, both PM association and employing organization should recognize and protect PM professionals' job mobility.

Among the 3 sub-commitment of PC, Chinese PM Professionals' Career Pursuit Commitment is significantly higher than Leisure Time Commitment $(p<0.001)$, and their Reference Group Commitment is also significantly higher than Leisure Time Commitment $(\mathrm{p}<0.001)$. All the 3 sub-commitments are significantly positively correlated $(\mathrm{p}<0.001)$. The relatively lower Leisure Time Commitment is understandable. On the one hand, PM Professionals are encouraged to contribute as more leisure time as possible to the PM profession. On the other hand, they cannot be expected to contribute the majority of their leisure time to the PM profession, except for the very limited number of top PM experts who regard professional activity itself as leisure activity.

The mean score of 3.56 with a standard deviation 0.68 represents that Chinese PM Professionals have developed a not-low level of Leisure Time Commitment. Since PMI established its China office at Beijing in 2004, PMI's Chinese volunteer community has been developing very quickly. The core volunteer teams frequently hold PM professional activities in leisure time. In addition, many PM training companies are very active in attracting PM Professionals to participate their PM professional activities in leisure time. PM professionals' Leisure Time commitment can further promote the development of the PM profession, and enhance organizational adoption of the PM approach.

Chinese PM Professionals' Career Pursuit Commitment and Reference Group Commitment are both quite high, representing that they have well established PM as a permanent career and PM peers as a reference group. In the first decade of the 21 st century, the changes in business make project management a popularly accepted career. It is reasonable that the majority of those individuals holding a PMP certificate regard PM as their permanent career instead of a stepping stone to another profession. Chinese PM Professionals' use of other PM Professionals as a reference group is certainly positively associated with their view of the PM profession as a terminal career. They pursue PM as a career, and consequently they desire to be compared with other PM Professionals and accepted by other PM Professionals. This reference group commitment will in turn reinforce 
the career pursuit commitment. Chinese PM Professionals' common title 'PMP' is very important for them to develop their strong reference group commitment. No matter an individual's actual job position is senior manager, project manager, functional manager, or team member, all of them can call themselves and be called 'PMP'. Without such as a common title, it may be very difficult for people to identify with each other. PM associations and employing organizations should work together to establish and maintain a PM career ladder and a PM reference group in order to keep and even further increase PM professionals' work commitment.

\subsection{Demographics' Impacts on $P C$ and $O C$}

Chinese PM Professionals' job positions have significant impact on their PC. Those PM professionals on a senior manager position are committed significantly higher to the PM profession than others. The possible reason is that they have achieved great success by using the PM approach, and they desire to use the PM approach to maintain the success or even to achieve greater success. This finding has significant implications to PM associations. They should use those PM Professionals on senior manager position as leaders of local PM communities. Those PM Professionals can play a much more important role in promoting the development of the PM profession and community.

Chinese PM Professionals with 6 years and more PM practical experience are committed to the PM profession significantly higher than those with below 3 years experience. This finding confirms previous studies that suggest that practical experience is an important factor in determining professionals' work commitment, such as Lian (2004). As is accumulated their PM experience, PM Professionals' commitment to the profession increases. This finding also justifies the PMI's requirement that says an individual is ineligible to sit the PMP exam until he (she) has at least 3 years or 5 years PM experience.

Chinese PM Professionals with 9 days and more formal PM training are committed to the PM profession significantly higher than those with below 9 days training. This finding suggests that formal PM training is very important to enhance members' professional commitment. PMI requires that an individual must complete a formal PM training course of minimum 35 hours before becoming eligible for applying for the PMP exam. In the China Mainland, many PMP preparation training courses are 9 days long. The PMI's 35 hours requirement and the 9 days PMP training courses can be justified by this research. In the formal training courses, PMP candidates can not only learn PM body of knowledge, but also shape their PM related values and beliefs.

\subsection{The Impacts of Organizational Factor 'PM Importance' on PC and OC}

Chinese PM Professionals working for those organizations which regard the PM approach important or very important are committed to the organizations significantly higher than those working for organizations regarding the PM approach as unimportant or very unimportant. This finding suggests that in order to increase PM Professionals' commitment to organizations, employing organizations must establish a PM system and make it an integrated part of the whole organizational management system. As this research shows, there are only 34 percent of organizations regarding the PM approach as important or very important. This means a very large potential for future improvement.

This research doesn't reveal that the degree to which an organization regards the PM approach as important has significant impacts on Chinese PM Professionals' commitment to the PM profession. However, from the descriptive statistical results, it can be concluded that, if an organization regards the PM approach as important or very important, PM Professionals' commitment to the PM profession will be further enhanced. Fortunately, PM associations have been doing many efforts to encourage organizations to adopt the PM approach.

\section{Conclusion}

This research provided some empirical evidence about Chinese PM Professionals work commitment. Firstly, the factor analysis of the survey data shows that Chinese PM Professionals' PC can be measured by the 3 dimensions, i.e., Career Pursuit Commitment, Reference Group Commitment and Leisure Time Commitment. This PC model was developed on the basis of defining characteristics of a professional community. It is more appropriate to be used for the purpose of promoting the development of the PM profession and community, compared with other PC models derived from relevant OC models. An individual is a true PM professional only if he (she) regards PM as a permanent career, uses other PM professionals as a reference group, and contributes some leisure time to the PM profession and community.

The research revealed that Chinese PM Professionals' PC and OC are significantly and positively correlated, and Chinese PM Professionals have developed good commitment to the PM profession. They have well established their PM Career Pursuit Commitment, PM Reference Group Commitment, and PM Leisure Time Commitment. Organizations and PM associations have a good basis for working together to achieve win-win development. 
Due to Chinese PM Professionals' PC is relatively higher than their OC and the positive correlation between their PC and OC, employing organizations should encourage PM professionals to commit themselves to the PM profession, so that their OC would be consequently enhanced.

Chinese PM Professionals' job position, work experience and formal PM training have significant impacts on their professional commitment. The higher their job position is, the more committed they are to the PM profession. The longer their work experience is, the more committed they are to the PM profession. Those PM Professionals with 9 days or more formal PM training is significantly more committed to the PM profession than those with below 9 days training. These findings have significant implies to the PM profession.

If an organization regards the PM approach as important or very important, its employing PM Professionals' OC would be significantly increased, and their PC can also to some degree be enhanced (although not statistically significantly). This finding can encourage employing organizations to systematically adopt the PM approach.

\section{Reference}

Aranya, N., Pollock, J., \& Amernic, J. (1981). An examination of professional commitment in public accounting. Accounting, Organizations and Society, 6(4), 271-280. http://dx.doi.org/10.1016/0361-3682(81)90007-6

Baugh, S. G., \& Roberts, R. M. (1994). Professional and organizational commitment among engineers: conflicting or complementing. IEEE Trans Eng Manage, 41(2), 108-114. http://dx.doi.org/10.1109/17.293377

Blau, G., \& Lunz, M. (1998). Testing the incremental effect of professional commitment on intent to leave one's profession beyond the effects of external, personal, and work-related variables. Journal of Vocational Behavior, 52(2), 260-269. http://dx.doi.org/10.1006/jvbe.1997.1601

Bredillet, C.N. (2009). The deployment of project management: A prospective view of G8, European G6 \& Outreach 5 countries in 2025. In David Cleland and Bopaya Bidanda (Eds.), Project Management Circa 2025. Pennsylvania: Project Management Institute.

Chen, S., Chang, S., Lin, H., \& Chen C. (2008). Post-SARS knowledge sharing and professional commitment in the nursing profession. Journal of Clinical Nursing, 18, 1738-1745. http://dx.doi.org/10.1111/j.1365-2702.2008.02488.x

Dwivedula, R., \& Bredillet, C. N. (2010). The relationship between organizational and professional commitment in the case of project workers: Implications for project management. Project Management Journal, 41(4), 79-88. http://dx.doi.org/10.1002/pmj.20196

Dwyer, P. D., Welker, R. B., \& Friedberg, A. H. (2000). A research note concerning the dimensionality of the professional commitment scale. Behavioral Research in Accounting, 12, 279-296.

Gouldner, A. W. (1957). Cosmopolitans and locals: Toward an analysis of latent social roles-1. Administrative Science Quarterly, 2, 281-306. http://dx.doi.org/10.2307/2391000

Greenfield, A. C., Jr., Norman, C. S., \& Wier B. (2008). The effect of ethical orientation and professional commitment on earnings management behavior. Journal of Business Ethics, 83, 419-434. http://dx.doi.org/10.1007/s10551-007-9629-4

Hoff, T. J. (2000). Professional commitment among US physician executives in managed care. Social Science \& Medicine, 50(10), 1433-1444. http://dx.doi.org/10.1016/S0277-9536(99)00410-4

Irving, P. G., Coleman, D. F., \& Cooper, C. L. (1997). Further assessments of a three component model of occupational commitment: Generalizability and differences across occupations. Journal of Applied Psychology, 82(3), 444-452. http://dx.doi.org/10.1037/0021-9010.82.3.444

Lee, K., Carswell, J. J., \& Allen, N. J. (2000). A meta-analytic review of occupational commitment: Relations with person- and work-related variables. Journal of Applied Psychology, 85(5), 799-811. http://dx.doi.org/10.1037/0021-9010.85.5.799

Li, Y., \& Shi, J. (2007). Professional commitment, organizational commitment and job satisfaction: An empirical study of project managers. Productivity Research, 16, 123-124.

Lian, R. (2004). A comparative research on the mental character of novice, proficient and expert teachers. Acta Psychologica Sinica, 36(1), 44-52.

Little, J. W. (2006). Professional Community and Professional Development. Retrieved from http://www.nea.org/assets/docs/professionalcommunitypd06.pdf (May 5 2011) 
Liu, Y. (2006). A study on the occupational commitment factor structure of telecommunication staff. Psychological Science, 29(4), 994-997.

McComb, E. D. (2006). An evaluation of the three-component model of occupational commitment among New Zealand general practitioners. Otago Management Graduate Review, 4, 67-87.

Meyer, J. P., Allen, N. J., \& Smith, C. A. (1993). Commitment to organizations and occupations: Extension and test of a three-component conceptualization. Journal of Applied Psychology, 78(4), 538-551. http://dx.doi.org/10.1037/0021-9010.78.4.538

Morrow, P. C. (1993). The Theory and Measurement of Work Commitment. Greenwich, Connecticut: JAI Press Inc.

Parker, S. (1972). The Future of Work and Leisure. London: Paladin.

PMI. (2011). Project Management Professional (PMP) Handbook. Retrieved from www.pmi.org (May 52011 )

Salaman, G. (1974). Community and Occupation: An Exploration of Work/Leisure Relationships. London: Cambridge University Press.

Stewart, T. A. (1995). Planning a career in a world without managers. Fortune, 131(5), 72-80.

Tang, L., \& Duan, J. (2006). The influence of commitments at multi-1evels 0n turnover intention in information technology companies. Chinese Journal of Applied Psychology, 12(4), 374-378.

Teng, C., Dai, Y., Shyu, Y. L., Wong, M., Chu, T., \& Tsai, Y. (2009). Professional commitment, patient safety, and patient-perceived care quality. Journal of Nursing Scholarship, 41(3), 301-309. http://dx.doi.org/10.1111/j.1547-5069.2009.01289.x

Van Maanen, J., \& Barley, S. R. (1984). Occupational communities: culture and control in organizations. In B.M. Staw and L.L. Cummings (Eds.), Research in Organizational Behavior, 6, 287-365. Greenwich, Conn: JAI Press.

Wahlstrom, K. L., \& Louis, K. S. (2008). How teachers experience principal leadership: the roles of professional community, trust, efficacy, and shared responsibility. Educational Administration Quarterly, 44(4), 458-495. http://dx.doi.org/10.1177/0013161X08321502

Wang, X., \& Armstrong, A. (2004). An empirical study of PM professionals' commitment to their profession and employing organizations. International Journal of Project Management, 22, 377-386. http://dx.doi.org/10.1016/j.ijproman.2003.09.004

Wang, X. (2001). Identification and Evaluation of the Key Attributes of Project Management Culture. PhD Thesis, Victoria University, Australia. Retrieved from http://eprints.vu.edu.au/15456/ (March 12011 )

Yetmar, S. A., \& Eastman, K. K. (2000). Tax Practitioners' Ethical Sensitivity: A Model and Empirical Examination. Journal of Business Ethics, 26, 271-288. http://dx.doi.org/10.1023/A:1006294517573 